\title{
Beyond 'do-no-harm': development, social safeguards policies, and human rights
}

\author{
Jayantha Perera* \\ Fellow, Royal Anthropological Institute, London, United Kingdom.
}

\begin{abstract}
Multilateral Development Banks (MDBs) have introduced environmental and social safeguard policies to protect the environment and improve human conditions. The paper attempts to demonstrate why MDBs should combine safeguard policies with the human rights to combat poverty and promote shared prosperity. It highlights MDBs' reluctance to link safeguards policies with human rights and how such reluctance has emboldened borrowers to ignore or to pay lip service to the human rights of development-affected persons and communities. In this context, MDBs need to update their safeguard policies to accommodate human rights and use approaches such as material incentives, persuasion, and long-term acculturation to encourage and lead borrowers to adhere to safeguard policies and human rights in planning and implementing development projects. In 2013, in India, such persuasion and incentives resulted in introducing in 2013 a comprehensive social safeguard framework covering physical displacement and resettlement and adverse project impacts on tribal people. Similarly, the Forest Dwellers Act of 2007 brought distinct benefits and a legal framework for tribal people to gain benefits of development and respect for their human rights. In Sri Lanka, a series of procedural reforms introduced from 2001 to the Land Acquisition Act of 1950 has helped to include several international safeguard best practices in the local regulatory framework such as land compensation at replacement cost and assistance to the untitled land users. However, the continuity of urgency clause (Section 38a) of the Act weakens the reforms' impact.
\end{abstract}

Keywords: Safeguards, human rights, accountability, environment and multilateral development banks.

\section{INTRODUCTION}

The World Bank claims that the application of its safeguard policy and environmental and social standards would help borrowers take necessary actions to end extreme poverty and promote shared prosperity "in a sustainable manner for the benefit of the environment and their citizens" (World Bank, 2016: p. ix). This paper argues that such safeguard policies and standards can help borrowers better in ending extreme poverty and promoting shared prosperity, if linked with human rights. The paper first outlines the relationship between development and human rights, and between development and safeguard policies. Then it examines the relationship between good governance and social safeguard policies in the context of the Environmental and Social Framework of the World Bank (2016). Finally, the paper examines the desirability and possibility of combining safeguard policies and human rights for better development outcomes.

\section{DEVELOPMENT AND HUMAN RIGHTS}

The Universal Declaration of Human Rights of 1950 (UDHR) of the United Nations (UN) established common achievement standards for all peoples and nations. The Declaration is the foundation of international human rights law and legally binding international human rights treaties. The Declaration confirms that (a) the universal recognition of basic rights and fundamental freedoms are inherent in all human beings, (b) such rights and freedoms are inalienable and equally applicable to everyone, and (c) everyone is born free and equal in dignity and rights. Whatever the nationality, place of residence, gender, ethnic origin, color, religion, language, or any other status, the international community is committed to upholding dignity and justice for all.

"Corresponding author(jayantha.perera7@gmail.com; (iD https://orcid.org/0000-0001-8568-3434) 
The UDHR is a declaratory legal instrument. The UN took over two decades to make the common achievement standards binding human rights obligations through International Covenant on Civil and Political Rights (ICCPR) and International Covenant on Economic, Social, and Cultural Rights (ICESCR). Despite the consolidation of human rights in international law from 1950 to 1980 , the UN and MDBs could not establish a nexus between development and human rights (Forsythe, 1997). The main reason for this failure is the 'solipsism' of the World Bank. With most other multi-lateral development banks (MDBs), it considers "the safeguard standards are part of an endogenous legal structure and hierarchy, in which validity is produced without recourse to exogenous international legal sources" (Meerssche, 2017: p. 157).

The 1980s witnessed far-reaching changes in international development and practice. A vital trigger for these changes was the rapid development of international law, human rights law, and humanitarian law, impacting sustainable development, environmental protection, and eradicating poverty. The outcome of such development is the universal recognition of the right to development of all human beings and the indivisibility of political, economic, social, cultural, and human rights that buttress the right to development (Meron, 2006).

The UN adopted, in 1986, the Declaration on the Right to Development, reaffirming the UDHR, ICCPR, and ICESCR. The Declaration states that:

1) The human person is the central subject of development, and therefore, the beneficiary of the right to development;

2) Development projects, therefore, should take into account human rights and fundamental freedoms of human beings as well as their duties to the community; and

3) The above two can ensure freedom and fulfillment of human needs, and, therefore, states should promote and protect an appropriate political, social, and economic order for development.

The above broad framework provided a premise for MDBs to develop a robust safeguard policy framework for protecting the environment and ensuring developmentaffected-persons' welfare. However, the World Bank followed the 1970 National Environmental Policy
Act (NEPA) of USA as its first environmental safeguard policy framework. The NEPA was a pioneering piece of legislation for environmental protection at the state level, and some scholars at that time called it the Magna Carta on the environment (Eccleston, 2013). A key characteristic of the NEPA is that it does not recognise human rights. Likewise, the World Bank kept human rights out of its development assistance policy framework, ignoring rapid development of international human rights law. From the 1990s, other MDBs copied the safeguard policies of the World Bank. They too underplayed the importance of human rights for environmental protection and social welfare, and security. Each MDB seeks refuge against human rights in its Articles of Agreement, claiming that a human rights-focus development approach would violate the Articles. The reluctance of some MDBs to deal with human rights has continued into the third decade of the $21^{\text {st }}$ century, as shown in their recent safeguard framework updates (see Table 1).

In September 2020, an influential professional group comprising the UN rapporteur on the situation of human rights defenders, the UN working group on the issue of human rights and transnational co-operations and other business enterprises, the UN special rapporteur on the right to development, the UN special rapporteur on the rights of indigenous peoples, the UN special rapporteur on the issues of human rights obligations relating to the enjoyment of a safe, clean, healthy and sustainable environment, and the UN independent expert on the promotion of a democratic and equitable international order submitted an 'open letter' to the Secretary-General of the Finance of the 'Common Summit' of researchers and representatives of public development banks. The letter raised two matters relevant to the success of the Summit: (a) the standing of human rights in the Summit's Agenda, and (b) the space for civil society, human rights defenders, and affected communities to participate in the Summit. The letter requested the Summit organisers to create space for them at the Summit enabling them to provide inputs to the Summit, its deliverables, and to "the collective statement envisaged as being declared by all public development banks during the Summit itself" (Lawlor et al., 2020: pp. 1-2). The open letter illustrates the inferior status that human rights and meaningful participation of project-affected persons in development hold in public development banks' operations as recently as 2020. The letter also emphasises the need to link human rights with safeguard policies and standards to provide a better atmosphere for the project-affected persons to participate and benefit from development interventions. 


\section{BORROWERS AND SAFEGUARD POLICIES}

During the past 20 years, the scope of environmental safeguard policies of MDBs has expanded from assessing project impacts, planning and managing impact mitigation measures to monitoring biodiversity, conservation and sustainable management of natural resources, pollution prevention, climate change, occupational and community health and safety, and preservation of physical and cultural resources. Parallel to the broadening of environmental safeguard policy scope, the social safeguard policy scope has also been widened. Social safeguards policies now cover physical and economic displacement resulting from the involuntary land acquisition or involuntary restrictions on land use or access to legally designated parks and protected areas, indigenous peoples, gender equality, labour and their working conditions, and nondiscrimination, stakeholder engagement, and information disclosure. However, environmental and social safeguard policies and standards still pay attention to human rights "to a very minor extent" (Meerssche, 2017: p. 157).

MDBs nudge borrowers to adopt safeguard best practices and improve their country safeguard systems (CSS). MDBs help borrowers and clients build their institutional capacity, start legal reforms, and inculcate good governance practices into development administration. Such assistance has helped some borrowers to revamp their CSS. India, for example, in enacting its 'Scheduled Tribes and Other Traditional

Table 1: Multilateral Development Banks and Human Rights Policies

\begin{tabular}{ll}
\hline Bank & Policy on Human Rights (HR) \\
\hline The World Bank & The ESF (2016) supports: (a) \\
& realization of HR listed in UDHR in \\
& projects it finances and (b) member \\
& countries to progressively achieve their \\
& HR commitments.
\end{tabular}

Asian Development Bank (ADB)

European Bank for Reconstruction and Development (EBRD)

Inter-American Development Bank (IDB) Investment Bank (AIIB)
A passing reference to HR of Indigenous peoples in Safeguard Policy Statement of 2009.

The Environmental and Social Policy (ESP) and Performance Requirements (PRs) (2019) reaffirm the Bank's commitment to respect human rights in its lending operations. HR due diligence is part of project review and requires its clients to identify HR risks in their projects. EBRD will not finance projects that contravene country obligations under international human rights treaties and agreements.

The environmental and social policy framework (ESPF) of 2020 elevates respect for human rights to the core of environmental and social risk management.

Environmental and Social Framework (2016) and its amended version (2020) support HR and encourage respect for HR in a manner consistent with its Articles of Agreement.

\section{HR addressed}

The ESF removes barriers and allows all, including vulnerable people, to benefit from development projects. No mention of HR in safeguard standards.

The SPS refers to labor, land ownership, and indigenous land rights without highlighting their HR aspects.

The rights of workers and vulnerable people, including indigenous peoples, protection from gender-based violence and harassment are elaborated without any reference to human rights.

The ESPF includes standards on gender equality, labour, and working conditions aligned with the core international conventions and instruments.

Consistent with the sustainable development goals. Projects will ensure inclusion and empowerment of people to participate in and benefit from the development process.
Remarks

Reference to HR is in the nonbinding 'Vision' section of ESF. Any Bank action regarding HR has to be consistent with Articles of Agreement of the Bank.

The Independent Evaluation of SPS (2020) did not mention HR or the need for addressing them in the safeguard policy update.

Incipient recognition of $\mathrm{HR}$ of project-affected persons. Actions that 'respect' HR are in safeguard policy and procedures.

Progressive attempt at bringing HR into safeguards. Still, safeguard policies take precedence over HR on the assumption that safeguards cover HR issues adequately.

HR are mentioned in the Vision statement, but are aspirational, not binding. Similar to the World Bank and EBRD approach to HR is in the Vision and not in the safeguard standards. 
Forest Dwellers (Recognition of Forest Rights) Act' of 2006, adopted several international best practices from the World Bank's Indigenous Peoples Safeguard Policy (1998). It also adopted several best practices from the ILO Convention concerning Indigenous Peoples and Tribal Populations in Independent Countries, No. 169 of 1989, and the draft UN Declaration on Indigenous Peoples' Rights (2004). The Act provides a comprehensive legal framework to protect individuals and communities and their communal land and cultural rights. Likewise, the 'Right to Fair Compensation and Transparency in Land Acquisition, Rehabilitation, and Resettlement Act' of 2013 substantially improved the scope of safeguards for ensuring social welfare of project-affected communities. In Sri Lanka, the Asian Development Bank (ADB) and the World Bank have assisted the government in revamping and improving involuntary resettlement safeguards in the Land Acquisition Act of 1950. The ADB guided and assisted the Ministry of Land and Land Development (MLLD) from 1999 to 2001 in formulating a national involuntary resettlement policy. Its principles match the involuntary resettlement safeguard policy principles of the ADB and the World Bank. Since then, the MLLD has further revised and updated the Regulations of the Land Acquisition Act of 1950 on several occasions.

A common practice among many borrowers is to apply the safeguard policies and safeguard standards of donors only to the projects that they finance. Borrowers are reluctant to assimilate safeguard policies, standards, and best practices of MDBs into their CSS. Most of them keep MDBs' safeguard good practices as a parallel set of safeguard guidelines. MDBs usually use persuasion or gentle coercion to push borrowers towards adopting best safeguard practices. A borrower's reluctance or failure to apply an MDB's safeguard policy to a development project arises from complexities in social, environmental, and political organisations within which the borrower operates, and from the difficulties the government and the borrower encounter in diffusing social and legal norms that are embedded in safeguard policies and standards to the CSS (Goodman \& Derek, 2013). An example in this regard is the failure of MDBs to grasp the importance of pervasive common property relations in the Pacific region, and their continuing efforts to apply private, property-based land acquisition and compensation safeguard policies to development interventions (Perera, 2015).

MDBs, in recent years, have attempted to shift from 'rule-based' to 'results-based' safeguard compliance at the sector level to minimise borrowers' reluctance to apply MDBs' safeguard best practices to development projects. This shift has substantially transferred the ownership of and accountability for safeguard compliance to borrowers. This paradigm shift culminated in the World Bank's Environmental and Social Framework of 2016. The Framework encourages its borrowers to apply their own CSS to development projects after improving local institutional capacity to ensure project sustainability. The Bank is committed to

"supporting Borrowers in the development and implementation of projects that are environmentally and socially sustainable, and to enhancing the capacity of borrowers' environmental and social frameworks to assess and manage the environmental and social risks" (World Bank, 2016: p. 3).

\section{INTERNATIONAL LAW AND GOOD GOVERNANCE}

During the past 60 years, the UN has worked with member nations to ensure their safety from atrocities and population displacement that they had experienced during World War II. To avoid repetition, the UN has enacted declarations, covenants, and protocols. They have contributed to expanding the scope of international law, international human rights law, and international humanitarian law. The UDHR of 1950 set forth the protection of all human beings' economic, social, and cultural rights. The ICCPR and ICESCR codified them in treaty form and elaborated upon its principles. The ILO Convention Concerning the Protection and Integration of Indigenous and other Tribal and Semi-tribal Populations in Independent Countries of 1957 and the ILO Convention Concerning Indigenous and Tribal Peoples in Independent Countries of 1989 articulated tribal and indigenous peoples' rights vis-a-vis other communities. The UN Declaration on Rights of Indigenous Peoples of 2007 consolidated international law's incremental growth on tribal and indigenous peoples and their human rights (Perera, 2009).

The Stockholm Declaration on the Human Environment of 1972 and the Rio Declaration on Environment and Development of 1992 focused on the relationship between human beings and their environment in development interventions. The legal instruments adopted at the Rio Declaration of 1992, such as the Agenda 21 and the Convention on Biological Diversity, established a framework of international legal standards to protect and conserve the environment for the present and future generations. Three key sets of rights are now well established in international law regarding the relationship between sustainable development and 
environmental justice. First is the right to life, including the right to a healthy environment. The second is the customary communal property rights of indigenous and other local communities. The third is participatory and procedural rights, such as the right to be informed and the right to know if their property is acquired or affected by state-sponsored interventions (Magraw \& Lynch, 2006).

Despite significant developments in international governance, MDBs have been slow to adopt human rights best practices from international law to improve and strengthen their safeguard policies and standards. As a result, MDBs' safeguard policies stagnate, and continue to focus on managing physical displacement of communities, loss of ancestral domain, and environmental harm without explaining how to avoid such harm (Perera, 2011). Involuntary resettlement safeguard policies of MDBs take physical displacement of project-affected persons and communities as an inevitable side effect of development. They emphasise that by managing displacement and resettlement processes, a project could provide development opportunities to improve the affected peoples' life chances. This reformistmanagerial approach summarises the involuntary resettlement safeguard policy approach of MDBs to development (Dwivedi, 2002). Research projects on resettlement and development usually take the reformist-managerial approach, as found in Sorensen's 'Relocated Lives: Displacement and Resettlement within the Mahaweli Project' (1991), and Asthana's 'In Voluntary Resettlement: Survey of international Experience' (1996). A break from this approach is Perera et al.'s 'Implementing Best Practices in Involuntary Resettlement: A Case Study in Sri Lanka' (2016). It examines pre-displacement and post-relocation planning and policy issues of one of the transport infrastructure development projects in Sri Lanka.

MDBs have been reluctant to combine human rights with involuntary resettlement safeguard policies. For example, the international involuntary resettlement policy principle that a person who has lost a piece of land to a project is entitled to replacement cost, focuses on private property and its ownership, not on human rights of the person to live a decent life with a livelihood. In many countries, private property is not the dominant form of land ownership; it is owned and used as communal property. In this context, the emphasis on private property excludes many people from receiving assistance to restore their livelihoods or income sources. Where communal land tenure predominates, private property-related labels such as 'squatters' or 'encroachers' become less relevant. In this context, what is needed is to emphasise that the affected people are threatened by impoverishment, if relocated (Koenig, 2014). The emphasis on threatened impoverishment brings the issue to the realm of human rights.

Another involuntary resettlement safeguard policy principle is that informal dwellers or squatters on private or public property should receive compensation for the structures that they built and assistance in finding employment. In relocation programmes, land ownership decides whether a person is eligible for resettlement and rehabilitation assistance. In urban resettlement programmes, landownership does not play a role in persons' livelihood as much as their skills and social networks do. A human rights approach to this group of people would focus on what skills, knowledge, and networks they possess and how could the project help them to recover or improve their living standards. A human rights approach helps discard arbitrary categorisation of people such as 'titled', 'non-titled', 'encroachers', 'squatters', and 'informal dwellers', and also meager compensatory entitlements such as 'cash compensation for structures' with which they are expected to convert their economic and social vulnerabilities into development opportunities.

A critical issue in the international development discourse is why do MDBs not pay sufficient attention to international law, especially to international human rights standards, in updating their environmental and social safeguard policies and standards. First, MDBs as a group emphasise that they should not deal with human rights in sovereign countries because human rights are not in MDBs' Articles of Agreement. Any attempt to deal with human rights would therefore violates the injunction not to interfere with member states' political affairs (Clapham, 2006). In its Environmental and Social Framework, however, the World Bank has softened its position on human rights by planning to follow the UDHR in financing development projects.

Second, MDBs argue that development projects have beneficial impacts on the people, creating development opportunities for them, which would fortify human rights than breach them. Therefore, it is unnecessary, MDBs argue, to specifically emphasise human rights in doing business with borrowers and clients.

Third, MDBs believe that any attempt to promote human rights in their business models could undermine borrowers' sovereignty and the privileges of their favored ethnic groups and the elite. In this context, highlighting human rights is not conducive to development business. 
As a President of the World Bank pointed out,

"to some of our shareholders, the very mention of the word human rights is inflammatory language. Moreover, it is getting into areas of politics, and into the areas that they are very concerned about. We decide to just go around it, and we talk the language of economics and social development" (quoted in Clapham, 2006, p. 138).

Fourth, States are slow to ratify UN declarations and covenants that refer to human rights. Even after the acceptance and ratification, a State may take several decades to incorporate them in its national regulatory framework.

\section{GOOD GOVERNANCE AND SOCIAL SAFEGUARD POLICIES}

Social safeguard policies are a set of principles of good governance. Principles of good governance deal with transparency, participation, and accountability (Larsen \& Ballesteros, 2013). In the international development discourse, 'good governance' is a critical foundation for achieving positive social, environmental, and economic outcomes from projects and investments. However, any attempt to link social safeguard policies with good governance raises several questions. First, do social safeguard policies contribute to best governance practices that address the people's human rights? Second, can such policies encourage meaningful changes in state behavior towards the human rights of citizens? Third, under what forms of linkages - material inducement, persuasion, and acculturation-would a state effectively adopt international best governance and safeguard practices into their CSS? The answer to the first question is safeguard policies do not pay attention to human rights as much as governance principles and practices do. For example, the Safeguard Policy Statement of ADB (2009) mentions human rights only twice. Answer to the second question is social safeguard policies are limited in scope, as they primarily deal with land acquisition, compensation, and access to communal land and cultural rights issues. Therefore, they are not influential enough to change a state's behaviour to embrace human rights.

Regarding the third question, MDBs use material inducement and persuasion as mechanisms to influence borrowers to adopt international safeguard policies. Material inducements cannot penetrate the complexities of political, economic, and social environment within which a state operates. Persuasion often fails to account for ways in which the diffusion of social and legal norms would occur. In this context, what is sustainable is acculturation. Acculturation calls for a deep understanding of social, political, and economic forces, their composition, functions, and their interactions. Such an understanding would positively influence a state to pay attention to human rights in development interventions.

A borrower state finds it challenging to assimilate international social safeguard best practices because of their significant impacts on local legal, political, and economic systems. Such impacts could complicate the country's established patterns of power distribution. Moreover, most Asian, African, and Latin American countries orient their development policies towards the primacy of the state's rights and responsibilities for implementing development projects. In such a socio-political system, a state may use its archaic, but powerful legal instruments such as the right of 'eminent domain' and 'urgency clauses' of the Land Acquisition Acts to acquire land without consulting landowners and users. Such state rights are well entrenched in domestic legal systems, mainly in South Asian countries, where British colonial rule dominated. Section 38 of the Land Acquisition Act of Sri Lanka of 1950 is an excellent example of such archaic laws.

Section 38 of the Land Acquisition Act of 1950 clashes with international resettlement best practices and adversely affects the project-affected-persons' human rights in several ways. The 48-hour notice to vacate violates landowners' fundamental right to know about land acquisition, receive compensation before acquisition, and economic rehabilitation plans before acquiring and vesting land in the state. The state thus deprives landowners and land users of their human right to conduct meaningful consultation and negotiation. The state's power to remove landowners from the acquired land also confronts the resettlement best practice of allowing those who lost land to a project to stay on the acquired land until they find alternative land and housing. The impact of urgent land acquisition on them is severe and traumatic, and they will suffer economic, social, and psychological hardships. In such a situation, they are not development partners, but victims. The 'urgency clause' in the Land Acquisition Act of 1950 is an easy and quick way for the state to acquire land for a 'public purpose', and avoid the landowners' objections to acquiring of their land. Under the 'urgency clause', a landowner gets compensation after the acquisition of his land, and compensation payment could take several months or years. 
As mentioned above, the National Involuntary Resettlement Policy (NIRP) of 2001 introduced several international social safeguard best practices such as payment of cash compensation at replacement cost and recognition of untitled land users' rights and interests in the land. In 2008, the National Policy on Payment of Compensation established a uniform system of compensation payment. In 2009, the Parliament ratified Land Acquisition Regulations of the Policy of 2008. The impact of the policy and its regulatory changes are significant. Before the NIRP, the congruence level between the local regulatory framework for land acquisition, compensation, resettlement, and international best practices was about 55 per cent; after enacting the Regulations of 2009, the congruence level went up to 85 per cent (Sri Lanka, Ministry of Land and Land Development, 2013). Recent improvements in Sri Lanka's regulatory framework show that over time countries have been moving from 'State focused' legal and policy frameworks towards 'people-focused' development paradigms (Perera, 2016).

\section{NEW PARADIGM OF SAFEGUARD POLICIES}

One of the World Bank's key arguments for slimming down of its safeguard policies is that safeguard policy application is costly and can generate multiple interpretations of safeguard requirements, confusing borrowers. It assessed this possibility and recommended conducting 'second generation' empirical international studies to clarify social mechanisms that could effectively influence states' practices. As an initial step of this approach, the World Bank, in 2013, 'retired' its safeguard policy framework and the guidelines on social assessment which was an integral component of the project appraisal toolkit. After that, the World Bank compressed 13 of its operational policies into one single document-Environmental and Social Framework (ESF).

"All content-specific provisions for SIA [social impact assessment] were tossed out of the rewritten 2013 requirements for preparing and financing the World Bank's development investment projects' (Cernea 2016: p. xii).

Despite the criticisms of international NGOs and the UN Commission on Human Rights, the ESF has taken safeguard policies into a new realm where more clarity, simple procedures, and room for better interaction with borrowers are evident. It integrated different safeguard policies within a holistic, normative framework positioning it in international law, thereby increasing development effectiveness of projects and investments through more country ownership. Development effectiveness is a vital aspect of the Paris Declaration on Aid Effectiveness of 2013. Development effectiveness needed a boost with the changing profiles of borrowers and clients, and the ESF provided that boost. The ESF is more a managerial approach than a prescriptive one. Without demanding satisfactory planning instruments and commitment at the inception of a project, the ESF allows the Bank to support any project that is "expected to meet the safeguards requirements in a manner and within a timetable acceptable to the Bank" (World Bank, 2016: para. 7). Such a downstream managerial approach does not leave sufficient room to check whether project proposals and planning instruments contain any room to highlight the importance of human rights.

The ESF has substantively expanded the safeguard policy scope by adding new safeguard standards such as labor and working conditions, prohibition on child and forced labor, protection of collective bargaining, and freedom of association. However, the Bank was not ready to subject itself to any source of international human rights law. As a result, the limited reference to human rights in ESF is vague and aspirational (Meerssche, 2017).

The ESF has transferred the responsibility for ensuring the application of safeguard standards to development projects from the World Bank to the borrower. This critical change raises several issues. First, borrowers and clients may find that the revised scope of safeguard standards is beyond their grasp and expertise. In such a situation, the shift of responsibility for safeguard compliance from the Bank to borrowers could worsen human rights record, as borrowers would try to ignore human rights aspects of development projects as much as possible. Second, a borrower could claim that the donor-assisted projects promote human rights because they focus on poverty alleviation and vulnerable groups. In such a situation, the World Bank may not check the veracity of such claims or try to explain to the borrowers the importance of human rights. Third, the transfer of accountability from the World Bank to borrowers may generate a safeguard vacuum, at least initially, as borrowers and the Bank might try to absolve themselves from being responsible for safeguard compliance of projects. Fourth, the transfer of the responsibility for safeguard compliance to borrowers can effectively remove the leverage that the Bank has to nudge the borrowers not to violate human rights in MDB-assisted projects.

Despite the risks outlined above, several MDBs have closely followed the World Bank's ESF model in revamping their safeguard policies and standards. Examples are the European Development Bank (2019), 
Asian Infrastructure Investment Bank (2020), and InterAmerican Development Bank (2018) who redesigned their safeguard systems. They make perfunctory reference to human rights in the vision statements or preambles of new policies. Table 1 summarises the current level of attention key MDBs pay to human rights in safeguard planning and implementation.

\section{SAFEGUARD COMPLIANCE AND HUMAN RIGHTS}

Many countries have ratified a variety of international covenants, declarations, and protocols, which refer to environment and social development. They contain human rights and how to operationalise them in the development arena. They could guide MDBs on how to include human rights in safeguard policies and standards, and harmonise international law with safeguard policies. Because of MDBs' policy to maintain their safeguard policies and standards separate from international legal instruments, even though many countries have ratified international legal instruments, no significant legal reforms have been triggered in such countries pertaining to social safeguards.

MDBs depend on borrower's willingness and commitment to apply safeguard best practices to development interventions. When a borrower agrees to add international safeguard best practices into its CSS, such an agreement sometimes would carry the CSS beyond the expectations of MDBs. The Government of India, for example, changed its development approach from the 'state-centric' to a 'person-centric' under the Land Acquisition, Resettlement and Rehabilitation Act (2013). It pays more attention to the interests and rights of project-affected persons and communities than MDB safeguard policies do. Such countries have also displayed their willingness to move away from the 'do-no-harm' policy to a sustainable development paradigm. The state, development-affected persons, and ecosystems benefit from cooperation and communication. However, such countries are few, and most CSS still require robust regulatory reforms, capacity development investment, and better communication. These are the critical areas where MDBs could provide adequate technical assistance to borrowers.

Fundamental rights enshrined in a country's constitution provide an arena to build up human rights as development safeguards. However, states are often reluctant to take this opportunity because of the lack of political will, expertise, and resources. Moreover, as Seppanen (2017) pointed out, conceptual limitations in human rights discourse could also thwart a state's intention to adopt human rights-based approaches to development. It is difficult for a country to select international human rights instruments to suit local conditions, unless steady external support is forthcoming as expertise and resources. Sometimes international law may not provide a robust framework to a particular country to reform its development policy-making apparatus and legal system to accommodate human rights. In such cases, human rights promoters may incline to coin less precise and non-legal definitions of human rights. When such definitions fail to help build "a self-standing development policy framework for human rights-based development", they still would promote human rights as a "substantively empty conceptual shell" to guide social justice causes. The interplay between these versions of human rights-based approaches can produce "convoluted and anomalous policy frameworks which are unconvincing for many development practitioners" (Seppanen, 2017: p. 390).

When a borrower is reluctant to adopt a human rights approach to development or when the proposed human rights-based approach is too convoluted, MDB can play a critical role to help the borrower to overcome initial reluctance and confusion the approach would have generated. It is legitimate and essential for MDBs to compel borrowers to adhere to human rights in addition to safeguard policy compliance. Although the IMF primarily deals with economic issues, as the UN pointed out, it cannot absolve itself from the accountability for adverse human rights impacts of the programs that it supports (United Nations, 2017).

Given their rich resource bases, international standing, and long-term direct dealings with borrowers, MDBs are in an excellent position to encourage borrowers to respect international human rights standards in development projects. But, MDBs still stick to the view that they should not engage in human rights discourse because it would drag them to political affairs, violating their Articles of Agreement. However, in recent years, academics, lawyers, and development practitioners have pointed out that human rights are not exclusively in the realm of politics but also directly relevant to development, especially to redeem developing countries from poverty and establish the rule of law (Clapham, 2006).

The World Bank and other MDBs claim that they promote human rights through various channels such as poverty reduction projects, promotion of transparency and accountability in government policies, and the empowerment of civil society, which directly impact human rights. As Clapham (2006) pointed out, as 
UN agencies, the World Bank and IMF must fulfill obligations under international law. In this regard, the principles of the UDHR play the role of the customary international law. For example, in the Three Gorges Project in the Peoples Republic of China, the state could have used the international law rather than MDB-specific safeguard policies or standards to help the projectaffected people. International NGOs often accuse MDBs of human rights violations, and such critique of MDBs is gathering momentum (Moris, 1997). As a result, MDBs will have to fall in line with the rapid development of human rights law to safeguard the interests and rights of the persons who are affected by development projects. In this context, the Environmental and Social Framework of the World Bank and the safeguard policies and standards of other MDBs do not reach the expected yardstick.

\section{CONCLUSIONS}

A robust human rights regime at the country level can promote development-affected peoples' interests and rights. However, MDBs are reluctant to accept human rights as part of core social safeguard policies and standards by which they assess and monitor development projects. Development literature shows that MDBs and borrowers frequently fail to achieve these objectives (Perera, 2014). The key reason for this frequent failure is that those safeguard policies often remain external to the borrowers' governance structure. As a result, development projects suffer from limited ownership, lack of transparency, accountability, and weak commitment. Another reason is MDBs' reluctance to accept that social and environmental safeguards should be premised on a broad human rights framework such as the one that the UN has developed over several decades. This reluctance among MDBs supports borrowers' reluctance and apathy to consider development rights as human rights.

MDBs should not be the enforcers of human rights law in borrower countries. However, they can do much more to protect the human rights of developmentaffected people and persuade borrowers to live up at least to the commitments they have made by ratifying the UN's international treaties, covenants, and declarations, and protocols. Paying lip service to the UDHR is not enough to protect the environment and human society from the adverse impacts of development. MDBs should develop a substantive safeguard system that recognises developed-affected persons' human rights to examine the effects of development projects that they fund on the environment and human society and how to ensure such rights are delivered adequately.
Human rights advocates have criticized the World Bank's ESF. They have pointed out that the World Bank's readiness to apply universal human rights to development projects is still an aspirational goal. The World Bank and IMF, as UN agencies, encounter the UN's demand to incorporate human rights law and humanitarian law into their safeguard policies, standards, frameworks, and project operations through which they aim to eliminate poverty and share prosperity. They cannot exclude human rights from their development discourses, as safeguard policies are relevant to international and domestic development discourses in an economic and moral sense. Safeguard policies and standards will have a better chance of compliance, backed by local legal systems and international scrutiny, if reintroduced as sound governance principles of customary international law.

International law is ahead of MDBs' safeguard frameworks and standards in reaching project-affectedpersons and communities to establish citizen-driven grievance redress mechanisms to redress their concerns and complaints. One advantage of labelling such concerns and complaints as human rights violations is that it would bring not only the project authorities but also the states into accountability. The nexuses between the state, MDBs, project authorities, and project-affected persons provide a foundation for establishing and operating a multi-tiered safeguard system starting from the projectlevel or subproject-level all the way up to the state, and finally to the accountability mechanisms of MDBs.

\section{REFERENCES}

Asian Development Bank (ADB) (2009) Safeguard Policy Statement, Manila: Asian Development Bank.

Asthana, R. (1996) Involuntary Resettlement: Survey of International Experience, Economic and Political Weekly, 31(24), pp: 1468-1475.

Cernea, M. M. (2016) Foreword - Social Impact Assessments and Safeguard Policies at a Fork in the Road: The Way Forward Should Be Upward, In Hari Mohan Mathur (ed) Assessing the Social Impact of Development Projects: Experience in India and Other Asian Countries, Switzerland: Springer International Publishing, pp: vii-xxiv.

Clapham, A. (2006) Human Rights Obligations of Non-State Actors, Oxford: Oxford University Press.

DOI:https://doi.org/10.1093/acprof:oso/

9780199288465.001 .0001 
Dwivedi, R. (2002) Models and Methods in DevelopmentInduced Displacement, Development and Change, 33(4), pp: 709-732.

DOI: https://doi.org/10.1111/1467-7660.00276

Eccleston, C. H. (2013) NEPA and Environmental Planning: Tools, Techniques, and Approaches for Practitioners, Boca Raton, Florida, USA: CRC Press, Tylor \& Francis Group.

Forsythe, D. P. (2012) Human Rights in International Relations, Cambridge: Cambridge University Press.

DOI: https://doi.org/10.1017/CBO9781139059114

Goodman, R. \& Derek, J. (2013) Socializing States: Promoting Human Rights through International Law, Oxford: Oxford University Press.

DOI:https://doi.org/10.1093/acprof:oso/

9780199300990.001.0001

Koenig, D. (2014) Reconstructing and Improving Livelihoods among the Urban Displaced: Lessons from Mumbai, India, In J. Perera (ed.) Lose to Gain: Is Involuntary Resettlement a Development Opportunity?, Manila: Asian Development Bank.

Larsen, G. \& A. Ballesteros (2013) Striking the Balance: Ownership and Accountability in Social and Environmental Safeguards, A Working Paper, Washington, DC: World Resources Institute. [Online] Available from: http://www. wri.org/publication/striking-the-balance-ownership-andaccountability-in-social-and-environmental-safeguards [Accessed: 15 ${ }^{\text {th }}$ July 2015].

Lawlor, J. et al. (2020) Joint Letter to Secretary General of the Finance in Common Summit [Online] Available from: www. ohchr.org $>$ Documents $>$ Issues $>$ Defenders $>$ joint [Accessed: $15^{\text {th }}$ February 2021].

Magraw, D. \& Lynch, O. (2006) One Species, One Planet: Environmental Justice and Sustainable Development, The World Bank Legal Review: Law, Equity and Development, 2, pp: 441-482.

Meerssche, D. V. D. (2017) Accountability in International Organisations: Reviewing the World Bank's Environmental and Social Framework, In E. Sciso (ed.) Accountability, Transparency, and Democracy in the Functioning of Bretton Woods Institutions, Cham, Switzerland: Springer International Publishing.

Meron, T. (2006) The Humanization of International Law, Leiden: Martinus Nijhoff.

Moris, H. (1997) The World Bank and Human Rights: Indispensable Partnership or Mismatched Alliance?, ILSA Journal of International and Comparative Law, 4, pp:173-200.
Perera, J. (2011) The limitations of current approaches to resettlement, In H. M. Mathur (ed) Resettling Displaced People: Policy and Practice in India, London: Routledge.

Perera, J. (2015) Assessing Land for Development: Best Practices and Country Systems in the Pacific Region, Asian Development Bank, Manila (unpublished).

Perera, J. (2014) (ed.) Lose to Gain: Is Involuntary Resettlement a Development Opportunity?, Manila: Asian Development Bank.

Perera, J. (2009) (ed) Land, and Cultural Survival: The Communal Land Rights of Indigenous Peoples in Asia, Manila: Asian Development Bank.

Perera, J. (2016) Rehabilitating Livelihoods: The IncomeGenerating Strategy for The People Affected by a Transport Project in Sri Lanka, In H. M. Mathur (ed) Assessing the Social Impact of Development Projects - Experience in India and other Countries, London, Springer International Publishing.

DOI: https://doi.org/10.1007/978-3-319-19117-1_12

Perera, J., Gamaathige, A. \& Werackody, C. (2016) Challenges in Implementing Best Practices in Involuntary Resettlement: A Case Study in Sri Lanka, Manila: Asian Development Bank.

Seppanen, S. (2017) From Substance to Absence: Argumentative Strategies in the Implementation of the Human Rights-Based Approaches to Development, International Law and Politics, 49, pp: 389-441.

Sorensen, B. (1996) Relocated Lives: Displacement and Resettlement within the Mahaweli Project, Amsterdam: VU University Press.

Sri Lanka, Ministry of Land and Land Development (2013) Land Acquisition and Implementation of the National Involuntary Resettlement Policy: A Guide for Public Officials on Good Practices, Colombo, Ministry of Land and Land Development.

United Nations (2017) Report of the Independent Expert on the promotion of a democratic and equitable international order, A/72/187 2/28 17-12400, New York: United Nations.

World Bank (2016) Environmental and Social Framework, Washington DC: The World Bank. 